Article

\title{
Towards Decision-Making for the Assessment and Prioritization of Green Projects: An Integration between System Dynamics and Participatory Modeling
}

\author{
Gerard Olivar-Tost ${ }^{1,2, *}$, Johnny Valencia-Calvo ${ }^{1}\left[\right.$ and Julián Andrés Castrillón-Gómez ${ }^{2}$ (D) \\ 1 Department of Natural Sciences and Technology, University of Aysen, Coyhaique 5950000, Chile; \\ johnny.valencia@uaysen.cl \\ 2 Department of Electrical, Electronics and Computing, National University of Colombia, \\ Manizales 170003, Colombia; jacastrillong@unal.edu.co \\ * Correspondence: gerard.olivar@uaysen.cl; Tel.: +56-942145815
}

Received: 2 October 2020; Accepted: 11 December 2020; Published: 21 December 2020 updates

\begin{abstract}
This research article presents the integration of participatory modeling and system dynamics as a novel methodology for the consolidation of social dynamic models for the subsequent evaluation and prioritization of green projects in Colombian post-conflict communities. First, through participatory work carried out with a community, the citizen factors were identified, evaluated, and systematized in relation to the problems and needs of the region. Second, based on the results obtained, a simulation model based on system dynamics-which facilitates decision-making with regard to the evaluation of green projects-was calibrated. The proposed methodology lead to the conclusion that, with the participation of the community, and with a model based on the dynamics of the variables-such as supply and demand-for natural water and land resources, it is possible to warn decision-makers about variables that can lead to the maximization of investments, and thus to prioritize and select the most appropriate environmental, social, or economic initiatives that meet the needs or expectations of the involved community. In the future, the model could be used to facilitate the management, administration, and control of water and land resources by creating alerts called reserve margins.
\end{abstract}

Keywords: participation; community; systems dynamics; sustainable development; decision-making

\section{Introduction}

Citizen participation gained great importance in the 1990s. While it has always been recognized as the fundamental pillar of democracy, its power and application are limited, especially in relation to low-income communities, racial minorities, and indigenous groups, whose participation is degraded to its lowest levels of indoctrination and manipulation [1-3].

Currently, the gap between theory and reality remains wide, but since the end of the 20th century, citizen participation has begun a process of resignification through the combination of approaches and methods that have evolved in order to allow communities to express, share, and analyze their needs and problems. Through the self-knowledge of communities, they can propose, plan, act, and thus improve their living conditions. Surveys conducted by Chambers $[4,5]$ show that the power and popularity of the Participatory Rural Appraisal (PRA) are, in part, due to the unexpected analytical skills of the local people, when they are capitalized upon through a relaxed and trusting relationship with external facilitators, as indicated by Campbell [6], Häsler et al. [7] and Menconi, Grohmann, and Mancinelli [8]. 
Colombia, for its part, has not been oblivious to this process, and the post-conflict framework has become the ideal setting for the implementation of participatory actions. This is how communities affected by the conflict have embarked on new forms of development that provide them with a better quality of life and the non-recurrence of violence. This is the case in vereda El Pesebre, a rural area in the municipality of Tame in the department of Arauca, a region affected by armed conflict between 2000 and 2010, in which various initiatives have been implemented in order to promote the economic and social development of the region on the basis of associativity and community cohesion. This has enabled the region to become visible to governmental and international institutions, which have offered their support for the consolidation of their productive activities.

In this sense, this research presents Participatory Rural Appraisal (PRA) as a tool for social learning and community knowledge $[6,7,9,10]$. Likewise, this research indicates the ways in which the social, environmental and economic findings obtained through the PRA are analyzed and systematized in order to calibrate a system dynamics model according to the characteristics of the selected community. The participatory workshop not only allows for the calibration of the model, but also facilitates the obtention of citizen factors that, although they are often used by central government bodies to prioritize green projects, rarely differentiate the needs of a community from its particular contexts. In other words, the citizen factors obtained through the PRA are directly related to the particular problems, needs, and expectations of each community in which the proposed methodology is applied and, in this regard, can improve or facilitate decision-making.

Accordingly, the article is divided as follows: in the second section, the socioenvironmental and economic context of vereda El Pesebre, in which the workshop took place, is presented. In the third section, the development of the workshop, according to the methodology of the PRA, along with the results, analysis, and systematization employed, is explained. The citizen factors obtained are also explained here. In the fourth section, the dynamic hypothesis is presented. Then, in the fifth section, the system dynamics model is introduced. In the sixth section, the system of equations is detailed. In the seventh section, the corresponding simulations and analyses are conducted. Then, in the eighth section, an analysis of the results is presented and contrasted against some previous related research. Finally, the main research findings and future challenges for participatory modeling, system dynamics, and their integration with other methodologies are detailed.

\section{Context of Vereda El Pesebre}

Vereda El Pesebre is located south of the municipality of Tame in the department of Arauca in Colombia (Figure 1). It is surrounded by multiple natural resources and bioclimatic stages, thanks to the fact that part of its territory belongs to Nevado del Cocuy National Natural Park, in which the main rivers, pipes, and ravines that cross the region originate.

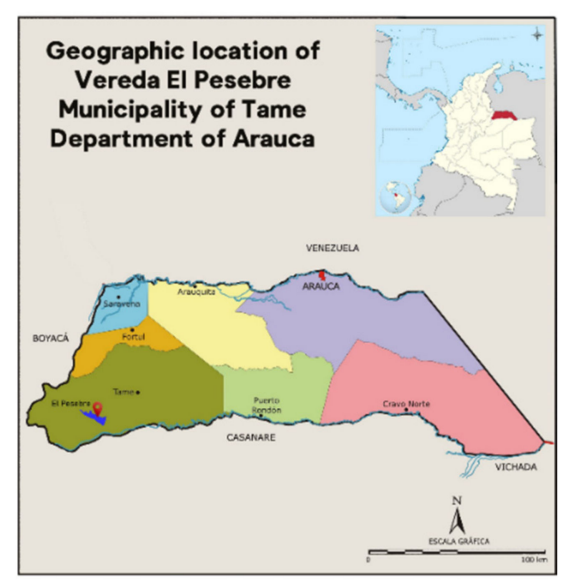

Figure 1. Geographic location of vereda El Pesebre. Source: Adapted from Milenioscuro, 2012; and SOGEOCOL, 2002. 
In the social and economic sphere, vereda El Pesebre was not unrelated to the conflict in the region and throughout the country, a situation that led this community, along with many others, to stagnation in terms of social and economic development. This backwardness was most noticeable in rural areas and in communities that coincided with the strategic corridors for armed groups, in which the war was most intense and often caused the displacement of their inhabitants.

It was in this way that, in the community of El Pesebre, the conflict led to a decrease in the capacity of its productive activities to supply the minimum needs of its inhabitants. These activities not only constituted the sustenance of families but were also an important part of the trade of the region. An important factor that slowed development even further was the forced displacement that occurred between 2007 and 2010, a period in which the territory was completely uninhabited and at the mercy of the armed groups that occupied the area.

\section{Theoretical Framework, Methodology and Development}

The proposed methodology is an integrated assessment approach based on Participatory Rural Appraisal (PRA) and System Dynamics Modeling (SDM). This approach exposes the synergies between PRA and SDM in order to inform decision-making in the evaluation and prioritization of green projects. This section illustrates these two techniques, highlighting their methodological background and operational characteristics.

\subsection{Participatory Rural Appraisal (PRA)}

Participatory Rural Appraisal (PRA), which was proposed in Chambers [4,5], has its roots in participatory activist research and Rapid Rural Assessment (RRA) [11], but focuses on public participation [12]. As a method belonging to the Action Research Models (ARM), PRA allows the establishment of connections between nature, its resources, and society, social learning and practice, and academia and the community [13]. It includes four essential elements: the empowerment of participants, collaboration through participation, knowledge, and social change [14].

Citizen participation methodologies, as research tools, have spread to much of the world since their use became popular in the 1970s [8]. Nowadays, these methodologies are used in various fields, and they are applied not only in social areas but also in environmental and economic areas, which promotes the sustainable development of communities. The techniques used in the PRA vary according to the target community and the proposed objectives. These techniques can also be classified into four groups: group dynamics, sampling, interviews, and visualization [15].

Another critical factor of PRA is related to the use of oral communication tools such as images, symbols, physical objects, and community memory to gather the necessary information [15]. PRA makes it easier for researchers and decision-makers to study the local community's responses through activities and discussions because it is considered a dual function methodology, i.e., it involves both data collection and information analysis.

Participatory Rural Appraisal (PRA) enables the development of social learning and community knowledge. It also facilitates social, environmental, and economic findings through dialogue and recreational activities. Besides this, its orderly structure facilitates the analysis and systematization of the results obtained in order to use them correctly; in the case of this research, it allows us to calibrate a model in system dynamics using what has been called 'citizen factors'. The power and popularity of Participatory Rural Appraisal are, in part, thanks to the unexpected analytical capabilities of local people when they are capitalized upon through an open and trusting relationship with external facilitators.

Through the PRA tools, it is possible to maximize the ability to control the natural resources that a community has. Likewise, environmental revenues can be maximized, and the changes required in governance for the proper management of natural resources can be managed. The above makes it possible to reaffirm what Reed [16] and Ling [15] said: the success of a project is directly related to the local community's level of commitment to it. 


\subsection{System Dynamics Modeling (SDM)}

This methodology, initially introduced by Forrester [17] for industrial problems and the compression of strategic processes, has also been successfully applied, since the 1960s, to the study of urban development. It gave rise to what has been known as the Urban Dynamics and, analogously, Regional Dynamics [18] methods, with which it was possible to build tools to assist in the planning and decision-making processes at the urban, regional and rural levels.

Systems Dynamics (SD) is not only focused on understanding the behavior of complex systems over time; it also seeks to capture internal feedback loops and time delays that could affect the behavior of the entire system. On the other hand, since it is a tool for the simulation of efficient scenarios, its use is appropriate in defining sustainable development policies $[19,20]$. This ability to quantitatively simulate various policies' dynamic consequences also makes it an ideal decision support tool for strategic policy selection and testing [21].

Furthermore, Systems Dynamics is structured in two parts: mathematical modeling and numerical methods of simulation; therefore, a model of this nature can also be considered a mathematical object, and it is pertinent to consider a mathematical analysis of its dynamics [22].

In recent decades, a growing number of SDM applications, such as transport [23], land use [24], environmental management [25], waste management [26], and sustainable urban development [18], have been recognized in the literature. Recently, the research presented in Castrillón-Gómez, Olivar-Tost, Valencia-Calvo [27], suggests that it is possible to model-in a participatory way-the socio-environmental and economic dynamics of a community concerning the uses that it makes of water and land, in order to select and prioritize the green projects that are planned to be implemented within it.

\subsection{Development of the Participatory Workshop}

The working methodology proposed was the Participatory Rural Appraisal (PRA), from which a workshop, 'Evaluating and Prioritizing our Resources', was prepared, which consisted of four sessions (lasting four hours each) and three phases of diagnostic, evaluative, and propositional work. These sessions and phases of work provided the necessary information for the calibration of a sustainable social system to carry out the evaluation and prioritization of green projects in vereda El Pesebre in Tame, Arauca.

The focus was on the community and its natural resources, mainly water and land. Likewise, this methodology was chosen because it is multidisciplinary, flexible, open, and collectivist, and thus generates active participation, interaction, the integration of knowledge, the improvement of skills and attitudes, and the refinement of decision-making processes within the community, which are useful for sustainable development in rural communities. In addition, this methodology allows for an analysis of the specific situation and the development of a common perspective on the management of natural resources and agriculture at the level of the participants. On the other hand, the evaluation and learning processes that take place during the workshops facilitate the identification of problems and generate the information necessary for the planning and the implementation of solutions, as well as their evaluation and monitoring.

What makes PRA different from other participatory methodologies is the way in which the problem of local knowledge-defined as the ability to understand or identify the full extent of local needs-is addressed. Participatory rural assessment enables diaries to overcome this difficulty by involving the community directly in the process of identifying and assessing the problem. Similarly, another distinctive aspect of PRA is analysis through shared visual representations by the local population, such as mapping or field modeling, or paper and other tools that facilitate the development of activities, as well as the verification and validation actions of the information.

As a motivational strategy for the attendance of the participatory workshops, an initial meeting was held in order to explain the purpose of the workshop and how it would be carried out. In addition, it was supported by the National University in Orinoquía, the United Nations Development Programme 
(UNDP (See further information on the organization's website: www.co.undp.org)) in the department of Arauca, and the GRANITA (See further information on the association's website: www.granita. simplesite.com) Association.

Taking into account the extension of vereda El Pesebre, the dispersion of its inhabitants, and the occupations and activities carried out by them in their daily working life, it was proposed that the workshop could be attended by one person as a representative of each family nucleus, which, on average, consists of four people. In this way, it can be said that the real participation exceeded $80 \%$ of the total number of families in vereda El Pesebre, which shows the interest for the workshop and the activities that were presented from the beginning.

Likewise, another factor that motivated the attendance was the interest of the facilitators in knowing the territory and its inhabitants, as well as its social, environmental, and economic dynamics. This created security for the participants, and it facilitated their active and sincere participation, since they did not need to have previous or specific knowledge on one topic or another; rather, it was a matter of learning about their daily life, environment, problems, needs, and expectations.

With regard to the development of the workshop, the diagnostic phase was implemented in the first session. The purpose of this phase was to identify the socioeconomic, productive, and environmental characteristics of the territory, and this was made possible by the development of collective tool-building activities, such as the SWOT matrix methodology and the Venn diagram, in which environmental, socio-cultural, economic, and productive issues were captured. In this session, the community was characterized by self-recognition. It was also possible for the facilitators to recognize these traits. Figure 2 shows the development of the diagnostic phase. At the end of the session, the technique of a semi-structured dialogue with some of the participants was applied, which sought to address issues that were not addressed, or that were not discussed in enough depth, such as the history of vereda El Pesebre, the population, and the different processes through which it passed, and the other processes which continue to occur in the community and territory. The session was summed up in the importance of the analysis of everyday life for the development and improvement of the quality of life in the communities. Table 1 presents the main issues identified in the diagnostical stage of the PRA.

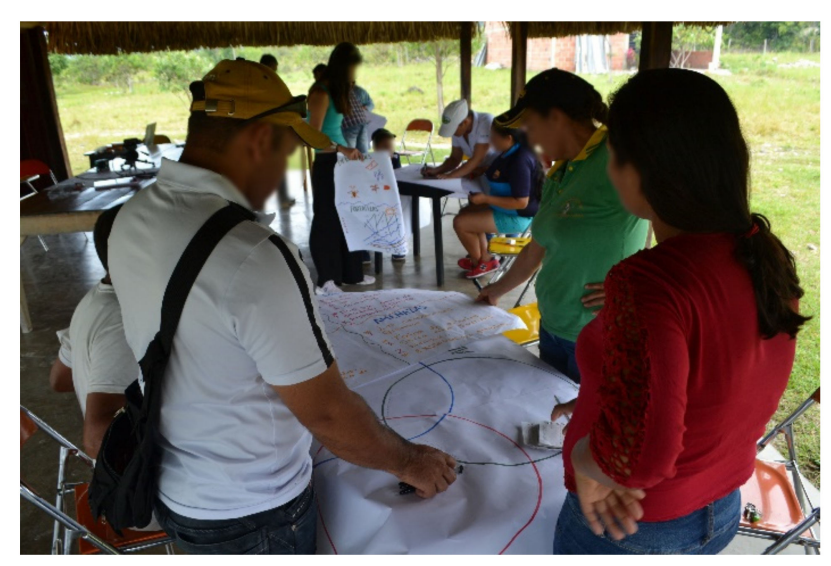

Figure 2. Development of the diagnostic phase. Source: authors' own creation. 
Table 1. Issues identified in the diagnostical stage of PRA.

\begin{tabular}{|c|c|c|}
\hline Issue Identified & Macro Area & Tool Used (Diagnostical Stage) PRA \\
\hline Scarce agricultural production & Socio-economic & Venn Diagram \\
\hline Infertile lands & $\begin{array}{l}\text { Socio-economic and } \\
\text { environmental }\end{array}$ & Venn Diagram \\
\hline Little research in the region & Socio-environmental & Venn Diagram \\
\hline $\begin{array}{c}\text { Weakness in training for agricultural } \\
\text { development }\end{array}$ & Social & SWOT \\
\hline Dependence on livestock activities & Economic & SWOT \\
\hline $\begin{array}{l}\text { Inadequate use of existing natural } \\
\text { resources in the region }\end{array}$ & Ambiental & SWOT \\
\hline $\begin{array}{l}\text { Inefficient targeting of training activities } \\
\text { and community work }\end{array}$ & Socio-economic & Venn Diagram \\
\hline $\begin{array}{l}\text { Waste of water sources, climatic } \\
\text { conditions, and knowledge of the region } \\
\text { to undertake tourism projects }\end{array}$ & $\begin{array}{l}\text { Socio-environmental } \\
\text { and economic }\end{array}$ & Semi-structured dialogue \\
\hline $\begin{array}{l}\text { Ignorance of the products derived from } \\
\text { beekeeping activities, being only } \\
\text { honey producers }\end{array}$ & Socio-economic & Semi-structured dialogue \\
\hline $\begin{array}{l}\text { Neglect and forgetfulness on the part of } \\
\text { the local government, along with } \\
\text { inadequate community management of } \\
\text { this government }\end{array}$ & Socio-economic and political & Semi-structured dialogue \\
\hline $\begin{array}{l}\text { Visibility of the community, allowing } \\
\text { other organizations and private } \\
\text { companies to forge a link with the region } \\
\text { through productive projects }\end{array}$ & Socio-economic and political & Semi-structured dialogue \\
\hline $\begin{array}{l}\text { Deforestation, indiscriminate logging, and } \\
\text { land burning }\end{array}$ & Environmental & Semi-structured dialogue \\
\hline $\begin{array}{c}\text { Displacement by violence and } \\
\text { depopulation of vereda el Pesebre } \\
\text { (2004 a 2011) }\end{array}$ & Social & Semi-structured dialogue \\
\hline $\begin{array}{l}\text { High transport costs (shortages and } \\
\text { current state of the roads) and difficulty in } \\
\text { marketing products }\end{array}$ & Economic & SWOT \\
\hline $\begin{array}{l}\text { Lack of security-related infrastructure } \\
\text { (police, army) and education (elementary } \\
\text { and high school) }\end{array}$ & Sociopolitical & Venn Diagram \\
\hline $\begin{array}{l}\text { Lack of sanitation (aqueducts } \\
\text { and sewerage) }\end{array}$ & Sociopolitical & Venn Diagram \\
\hline
\end{tabular}

The second session, which can be seen in Figure 3, consisted of a series of activities that sought a specific diagnosis of resources, such as water and land. One of the activities carried out was the construction of a map of natural resources and land uses, which showed some of the characteristics of the territory and the community that inhabits it. This activity was complemented by a tour of the territory given by the facilitators and some of the participants. Another activity was the seasonal calendar, in which the rainy and dry months were determined, and also the way they affect production, expenses, income, land and water sources, etc. Questions concerning the basic resources in the household were also asked. Finally, the session ended with the elaboration of a diagram in which the different types of lands, their characteristics, their uses, and their problems were specified. This diagram was made on the basis of the previous activities, which facilitated its development. 


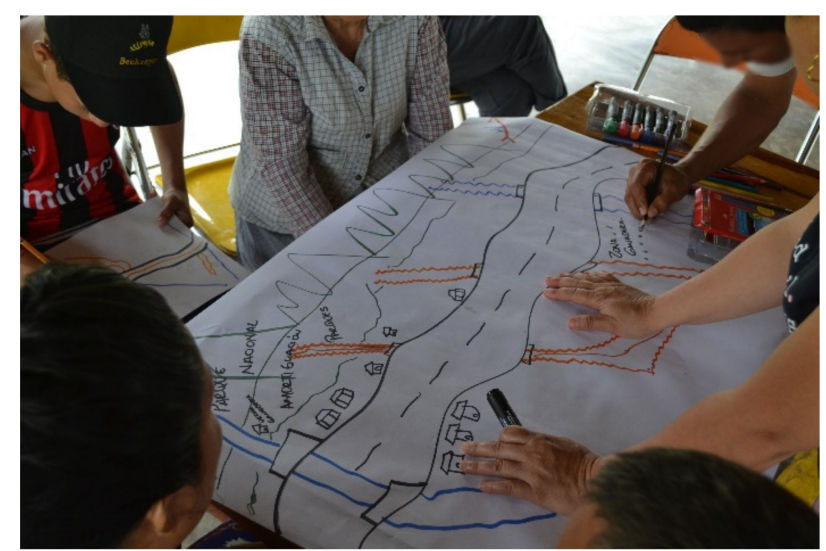

Figure 3. Development of the evaluative phase. Source: authors' own creation.

In the third session, the implementation of which is shown in Figure 4, the propositional phase was developed. The objective was for the community to assess the resources available in its territory, and their quality, quantity, access, and forms of use. A diagrama de cuenca, which sought to identify the natural resources available in the region, was proposed as a starting point, i.e., an initial activity for the discussion of the environmental interactions in the community's area of influence. After socialization, based on the information collected, activities such as the resource assessment matrix were developed. This activity allowed the participants to be the evaluators of resources such as water, land, pastures and crops, making their potentialities and weaknesses visible. The session ended with the development of questions related to the access to resources.

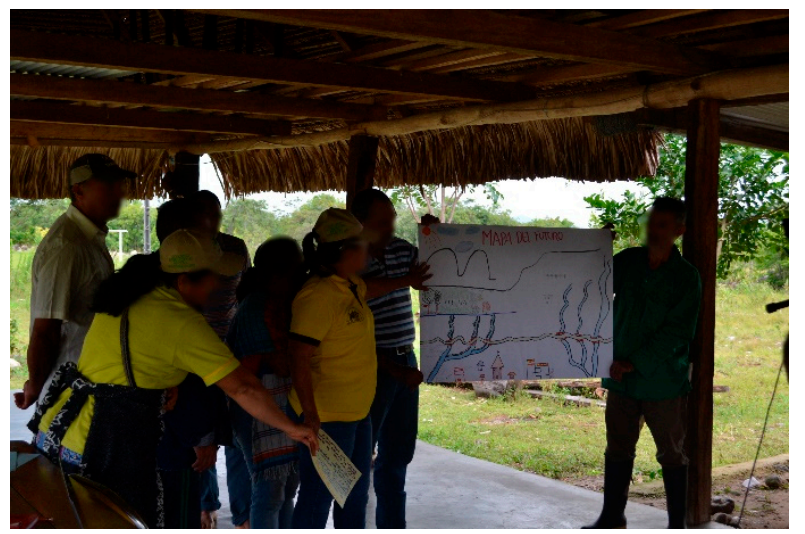

Figure 4. Implementation of the propositional phase. Source: authors' own creation.

\subsection{Outcomes of the Participatory Workshop}

The Colombian Orinoquía, the region in which vereda El Pesebre is located, has traditionally been associated with livestock and grazing activities. While this has been its main source of economic development within the surrounding territories, this activity has been reduced due to the low quality of the lands, the initial investment required, support costs, and difficulties associated with transport and commercialization.

In contrast, in vereda El Pesebre, there are other modes of production, such as agriculture and livestock, which do not have sufficient support (economic and technical) to allow these activities to promote the integral development of the community. Agriculture bases its activity on the production of food, such as cassava, bananas, and some fruits, which are destined only for self-consumption. A special case is the cultivation of coffee, which is currently in a period of strengthening and expansion within the families in El Pesebre. While coffee production is currently minimal, and does not represent 
a development factor for the community, it is projected to be a source of growth in the future, thanks to the already-existing national and international market [28].

On the other hand, the community is perceived to have high rates of social cohesion and literacy. In addition, another positive aspect that is highlighted in the community is the absence of problems related to drugs (crops, sale, and consumption). These qualities have allowed the community to have a healthy coexistence, and they enable environments for community entrepreneurship and associativity, as is the case in the apiculture project that has been developed in recent years, thanks the Granja Integral Tamarindo (GRANITA) association's ties to Agencia Promotora de Desarrollo Económico Regional (APRODEL (See further information on the organization's website: www.aprodelcolombia.org)), which develops this and other United Nations Development Programme (UNDP) projects in the region.

Thus, the support provided by these institutions in the region has become an engine of economic development for the inhabitants. In the specific case of the apiculture project, we observed that this activity has become one of the main sources of income for the inhabitants of vereda El Pesebre.

The community recognizes the water quality of its tributaries and identifies its main productive areas as ranging from the savannah to livestock and beekeeping, through the buffer zone or low mountains, up to the high mountain in Nevado del Cocuy National Natural Park, a protected and tourist area. However, the support they receive in order to undertake productive projects in any part of the territory is insufficient. Figure 5 shows the income perception of the inhabitants of vereda El Pesebre versus the use of the land destined for each productive activity.

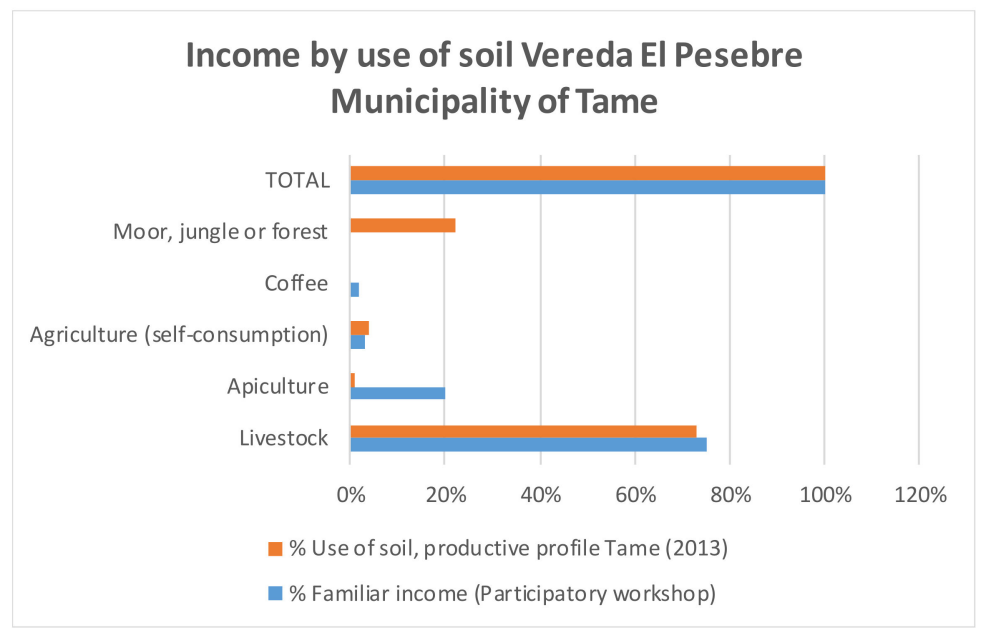

Figure 5. The income perception for land use. Source: authors' own creation.

It can be observed that, although livestock is still the main mode of production, to obtain a profitability close to $30 \%$ per year requires a high investment and a high consumption of land, water, and time.

On the contrary, apiculture, an activity that is being consolidated in the region, requires a considerably lower investment with respect to livestock, and its requirements in terms of water and land use are minimal, as is the demand for care. In addition, with this activity, it is possible to reach a profitability of nearly $40 \%$.

Something similar is true for the cultivation of coffee, which has recently started to be incorporated into the productive activities of the territory. Compared to apiculture, it requires more investment and a greater use of land and water, but this activity has the advantage of having a consolidated national market which guarantees the sale of all production. Other products, such as cassava and banana, which could reach a production of up to 1200 kilos per hectare, are not easily marketed in the area, which is why they are destined for consumption in El Pesebre. While this type of crop does not require irrigation other than that given by the rainy season, the areas in which they are produced are minimal. 
Additionally, the participatory workshop showed that, in vereda El Pesebre, the needs that the community considers urgent are related to the lack of social infrastructure, public services, health, and technology. This situation, as expressed by the inhabitants of the village, is a direct consequence of the armed conflict in the region. It was also possible to highlight other effects of the conflict, such as isolation, and social and economic discrimination. This was reflected over time in the inequity and low quality of life in the region, and, in general, it is shown by the fact that the community is considered to be a peripheral territory, with few opportunities for development.

With regard to the expectations and the projection of the community, the participatory workshop made visible the environmental awareness of the inhabitants, which was evident in their interest in the protection and reforestation of Nevado del Cocuy National Natural Park, and in their interest in caring for the rivers that are born there. This park is considered to be the central axis that can bring development to the territory, which is why the community expresses its interest in activities aimed at creating environmental awareness, and in green conservation projects that can be generated through rural and environmental tourism.

Similarly, the results of the workshop showed the marked influence that the development of apiculture has had on the economy. This influence is so great that the community expresses its interest in initiatives that-in the medium and long term-will allow them to create a collection center that will facilitate product logistics activities and their expansion at the regional and national levels.

Nonetheless, the community of vereda El Pesebre continues to see livestock as an important source of income in the future, but they also recognize the challenges that must be faced with regard to the processes of technification and reduction in environmental impact, in order for this activity to generate a greater income for the population.

With regard to the coverage and quality of services and public infrastructure, such as aqueducts, sewage, garbage collection, sports centers, educational institutions (elementary and high schools), and health posts, the community is excited to manage the necessary projects with local authorities. Likewise, they express an interest in achieving external alliances that will allow them to train the community regarding productive activities, and regarding the promotion of organized work and a sense of belonging and receptivity in its inhabitants.

In conclusion, the inhabitants of vereda El Pesebre highlighted that the activities carried out in the participatory workshop allowed them to strengthen the unity of the community, and to recognize their strengths as a group and also the wealth of natural resources in the region. Likewise, failures, bad practices and aspects to improve were identified, which can be transformed into productive projects or progress in terms of the improvement of the quality of life of their inhabitants.

This was made possible by the fact that the PRA methodology, applied in all of the sessions of the workshop, created bonds of trust with the facilitator team, which allowed the community to deepen its knowledge while generating relevant information and social learning. While not all of the community attended the workshops, a participation of about $20 \%$ was obtained, which showed the interest in the topics treated and, in general, in the future that awaits this community.

\subsection{Citizen Factors}

The participatory workshop developed with the community in vereda El Pesebre allowed the problems, needs, and expectations that arise at the social, economic, and environmental levels to be identified and prioritized. This, in turn, allowed the facilitator team to establish two citizen factors, that is, components that have a marked influence on the projects and initiatives that are carried out in the area, and that can also be expressed mathematically in the form of a percentage. These factors are the citizen water factor (CFwater) and the citizen land factor (CFland). According to these two factors, it is possible to determine what type of projects the community needs, prefers, or expects, depending on its current situation, and, in addition, it is possible to express it as a percentage amount that will affect-in one way or another-the results of the proposed model. 
Then, for each of the factors, CFwater and CFland, the facilitator team sought to establish, according to the results of the participatory workshop, the importance-in percentage terms-of those types of projects that may have greater relevance in the community. In this sense, three subcategories were defined for each citizen factor: the social sub-factor, the environmental sub-factor, and the economic sub-factor.

With respect to vereda El Pesebre, there were great differences between the defined citizen factors. On the one hand, although both resources are abundant in the area, the water is used in a better way, and is also more import for the inhabitants; on the other hand, the land resource has not only been wasted, but also underused, due to a lack of knowledge, and the lack of technical and financial support to start projects that directly involve it, such as agricultural projects.

Nevertheless, we also recognized that the main economic activity of the population, livestock, is due to the large areas of land in the region. Therefore, for the purposes of this research, it was decided that the following values would be given to the citizen water factors, according to the opinions and results of the participatory workshop:

$$
\begin{aligned}
& \text { Env CFwater : } 25 \% \\
& \text { Soc CFwater : } 30 \% \\
& \text { Eco CFwater : } 45 \%
\end{aligned}
$$

The following values were given to the citizen land factors:

$$
\begin{aligned}
& \text { Env CFsoil : } 20 \% \\
& \text { Soc CFsoil : } 30 \% \\
& \text { Eco CFsoil : } 50 \%
\end{aligned}
$$

In addition, it was found that the economic factor is the most important for the inhabitants of vereda El Pesebre. In this sense, the development, consolidation, and expansion of apiculture activities and the support of livestock are the actions that currently play a very important role in the local economy. Table 2 summarizes and defines the parameters by which the citizen factors were determined.

At this point, it is important to clarify the citizen factors considered in this research. While some of these may appear to be redundant, the citizen factors respond to two different concerns raised with the community by the facilitators of the participatory workshop. In principle, when talking about Economic, Social, or Environmental Importance, the intention is to learn which sector (social, environmental, or economic) has more relevance for its inhabitants and, therefore, should be promoted in order to achieve a rapid and efficient development of vereda El Pesebre. However, when talking about Importance in Economic, Social, or Environmental Projects, the intention is that the participants of the workshop recognize those types of projects that they consider more appropriate, a priority, or perhaps urgent for the community, regardless of the sector in which they are located and the considerations expressed regarding the above variables. 
Table 2. Citizen factors determined through the participatory workshop.

\begin{tabular}{|c|c|c|c|}
\hline Citizen Factors & Description & Value & Units \\
\hline IEn Water & $\begin{array}{l}\text { Importance of water-based environmental development versus } \\
\text { economic and social development, indicated by the community }\end{array}$ & 25 & $\%$ \\
\hline IEnP Water & $\begin{array}{l}\text { Importance of the development of Environmental Projects with a } \\
\text { focus on water versus other types of projects (social and } \\
\text { economic), indicated by the community }\end{array}$ & 25 & $\%$ \\
\hline IS Water & $\begin{array}{l}\text { Importance of water-based social development versus } \\
\text { environmental and economic development, indicated by } \\
\text { the community }\end{array}$ & 30 & $\%$ \\
\hline ISP Water & $\begin{array}{l}\text { Importance of the development of Social Projects with a focus on } \\
\text { water versus other types of projects (environmental and } \\
\text { economic), indicated by the community }\end{array}$ & 30 & $\%$ \\
\hline IEc Water & $\begin{array}{l}\text { Importance of water-based economic development versus social } \\
\text { or environmental development, indicated by the community }\end{array}$ & 45 & $\%$ \\
\hline IEcP Water & $\begin{array}{l}\text { Importance of the development of Economic Projects with a focus } \\
\text { on water versus other types of projects (environmental and social), } \\
\text { indicated by the community }\end{array}$ & 45 & $\%$ \\
\hline IEn Land & $\begin{array}{l}\text { Importance of land-based environmental development versus } \\
\text { economic and social development, indicated by the community }\end{array}$ & 20 & $\%$ \\
\hline IEnP Land & $\begin{array}{l}\text { Importance of the development of Environmental Projects with a } \\
\text { focus on land versus other types of projects (social and economic), } \\
\text { indicated by the community }\end{array}$ & 20 & $\%$ \\
\hline IS Land & $\begin{array}{l}\text { Importance of land-based social development versus } \\
\text { environmental and economic development, indicated by } \\
\text { the community }\end{array}$ & 30 & $\%$ \\
\hline ISP Land & $\begin{array}{l}\text { Importance of the development of Social Projects with a focus on } \\
\text { land versus other types of projects (environmental and economic), } \\
\text { indicated by the community }\end{array}$ & 30 & $\%$ \\
\hline IEc Land & $\begin{array}{l}\text { Importance of land-based economic development versus social or } \\
\text { environmental development, indicated by the community }\end{array}$ & 50 & $\%$ \\
\hline IEcP Land & $\begin{array}{l}\text { Importance of the development of Economic Projects with a focus } \\
\text { on land versus other types of projects (environmental and social), } \\
\text { indicated by the community }\end{array}$ & 50 & $\%$ \\
\hline
\end{tabular}

\section{Dynamical Hypothesis}

This research was based on the model defined by Castrillón-Gomez, Valencia-Calvo, and Olivar-Tost [27]. This system uses the principles of supply and demand set out in Dyner [22,29,30], but applied to the design of a sustainable development structure, in which two main attributes are used as bridges between the other attributes that complete the system: the first is determined by the relationship between the supply and demand for water; the second is determined by the relationship between the supply and demand for land.

In the same order, bridges refer to the reserve margins of water and land, and these reserve margins refer to the availability of each existing resource according to its use, and they were used as the elements that allowed for the interaction between the incentives for green projects and the investment that could be made available by the local government for the implementation of community initiatives.

According to Figure 6, the main hypothesis for the construction of the model is the impact of the investment decisions and incentives for investment in green projects, depending on the availability of natural water and land resources, and the citizen factors established through the participatory workshop which was previously conducted with the community. 


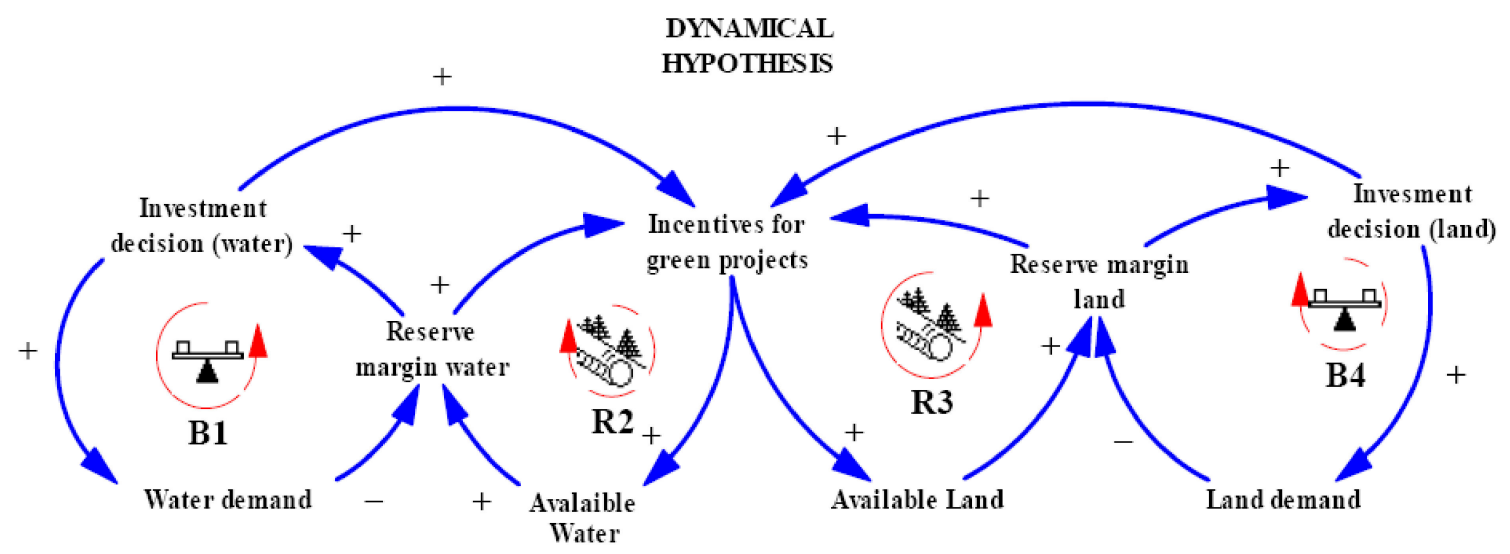

Figure 6. Dynamical hypothesis. Source: extract from Castrillón-Gómez, Valencia Calvo and Olivar-Tost [27].

While it is useful to build a reserve margin in order to monitor the current state of resources, it is also important to determine the degree of influence, represented by the citizen factor, that the community has over the prioritization of green projects, in such a way that it is not only possible to intervene in order to achieve a balance between the use and harnessing of resources, but also in accordance with the problems, needs, or expectations of the inhabitants.

As for the balance cycles, B1 and B4, shown in Figure 6, these correspond to the water demand and the land demand, respectively. Now, the R2 and R3 reinforcement cycles, which are responsible for the stabilization of the use of resources, thanks to their snowball effect, are also affected by the defined citizen factors, causing the prioritization of shifting proportionally towards the type of projects the community would expect to obtain. Through this approach, depending the on water and land reserve margins and citizen factors, new investments will be made in green projects. Just as negative reserve margins may indicate a scarcity in one resource or another, citizen factors will indicate which investments to prioritize when this occurs, which is information that may be key to rethinking the type of projects to be developed in the community and, in some way, to increasing their chances of success.

On the other hand, when reserve margins are positive, a balance in the use of resources or their abundance is evident. In this case, although the citizen factors are not evident within the model, it is useful for decision-making, because it provides information regarding the needs or expectations of the community, which allows the best initiatives to be raised and developed. It should be noted that this research is focused on the prioritization of projects in areas where water or land resources may be in short supply at some point.

\section{Simulation Model}

The flow and level diagram presented in Figure 7 corresponds to an adaptation of the work carried out by Castrillón-Gómez, Valencia-Calvo, and Olivar-Tost [27]. This diagram shows the variables of the proposed model, including an additional state variable corresponding to the population in this research. The dynamic hypothesis shown above is now detailed in a stock and flow diagram (SFD) $[17,31]$, in which two state variables, represented by rectangles, are considered. The others, considered as auxiliary variables, are represented with circles. The connections between the different variables represent the information flows, through which the flow of the material in the state variables is controlled. 


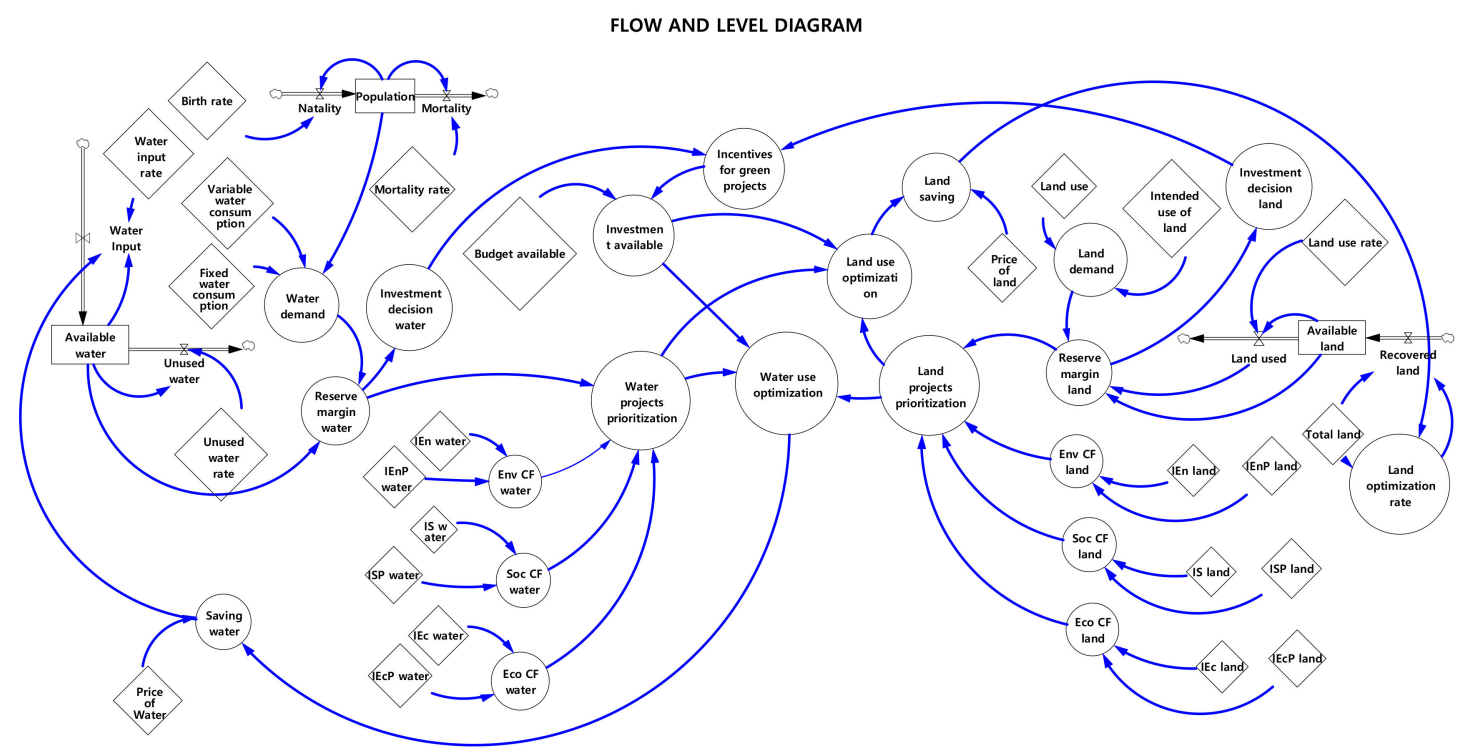

Figure 7. Flow and level diagram. Source: adapted from Castrillón Gómez, Valencia Calvo and Olivar-Tost [27].

In the diagram, we can see that the incentives for green projects are modeled as a piecewise function, in which the investments depend on the decision concerning water investment and the decision concerning land investment, while the variables of the optimization of the water use and the optimization of the land use respond not only to the financial factor (or the available investment) but also to the prioritization of projects, which are understood as citizen factors (environmental, social, and economic) as described above, and which were already defined with the community through the development of participatory workshops. Thus, it was possible to tune the model in such a way that the context, needs, and expectations of the community will be reflected in the system quantitatively, a situation that is usually not considered within government schemes or centralized institutional representations. The investment decisions in water and land refer to the availability of these natural resources, in this case, in the community of vereda El Pesebre. Therefore, these variables, together with the citizen factors, are the ones that affect in a greater or lesser proportion the model and, consequently, the decision-making in relation to the green projects that are planned to be developed in the area.

\section{System of Equations}

The flow and level diagram presented in Figure 7 is also a mathematical object, and it is possible to write it as a system of differential equations that represent the supply and demand of the natural resources of water and land, as motivators for investments in green projects.

$$
\begin{gathered}
\dot{r_{1}}=-a r_{1}+W \\
\dot{r_{2}}=-b r_{2}+L
\end{gathered}
$$

In Equation (1), $r_{1}$ corresponds to the available water resources, $r_{2}$ corresponds to the available land resources, $a$ corresponds to the index of unaccounted-for water, and $b$ corresponds to the rate of land use. In the case of the municipality of Tame, part of which is occupied by vereda El Pesebre, the index of unaccounted-for water is estimated at $31.68 \%$, according to data obtained from the management report on the aqueducts, waste management, and sewage companies in the region [32]. As for the rate of land use, it is estimated at $1.17 \%$, calculated according to the information given in the production profile of the municipality of Tame [33].

In relation to the water contributions, represented by $W$, vereda El Pesebre has the Lopeño and Lejía rivers as its main tributaries. Because the municipality does not have limnometric stations in any 
of the rivers, it is not possible to obtain an updated measure of its flows. However, considering that Lopeño River is ranked at number five (in terms of the number of tributaries), just after the Tame River, this model will assume the estimated flow rate of the river Tame, which is $23.96 \mathrm{~m}^{3}$ on average. On the other hand, another major water supply in the region is the annual rainfall, which has an average of $2890 \mathrm{~mm}$ per year. $W$, as shown in Equation (2), besides being defined as a continuous function, relies on the saving of this natural resource $\left(S_{\text {water }}\right)$, depending on the price per cubic meter (Price water), which, for this region, is valued at approximately 6000 Colombian pesos per $\mathrm{m}^{3}$ in rural areas. $L$ is the amount of land that can be optimized for the development of sustainable projects, which, for the particular case of the municipality of Tame, corresponds to the number of hectares in the process of technification (approximately 3933) [34]. L, as shown in Equation (3), is also a continuous function that relies on the savings achieved in this natural resource, expressed as $\left(S_{\text {soil }}\right)$, depending on the price per hectare, which, in the case of the department of Arauca (where vereda El Pesebre is located), has an average value of 150,000 Colombian pesos [9].

$$
\begin{gathered}
S_{\text {water }}=\frac{O_{\text {water }}}{\text { Price }_{\text {water }}} \\
S_{\text {soil }}=\frac{O_{\text {soil }}}{\text { Price }_{\text {soil }}}
\end{gathered}
$$

The land use optimization $\left(O_{\text {soil }}\right)$ and water use optimization $\left(O_{\text {water }}\right)$, represented in Equations (4) and (5), respectively, are defined as the percentages by which the available investment is divided (I):

$$
\begin{gathered}
O_{\text {soil }}=\left(1-\frac{P_{s}}{P_{w}+P_{s}}\right) * I \\
O_{\text {water }}=\left(1-\frac{P_{w}}{P_{w}+P_{s}}\right) * I
\end{gathered}
$$

where $P_{w}$ corresponds to the Water Project Prioritization, and is defined as a step function that depends on the water reserve margin $\left(R M_{w}\right)$ and the citizen factors found through community participation, which can be social $\left(C F_{s}\right)$, environmental $\left(C F_{e n}\right)$, or economic $\left(C F_{e c}\right)$. Likewise, $P_{s}$ corresponds to the Land Projects Prioritization, and is defined as a step function that depends on the land reserve margin $\left(R M_{s}\right)$ and the citizen factors identified through community participation, as described above: $\left(C F_{s}\right)$, $\left(C F_{e n}\right)$, and $\left(C F_{e c}\right)$.

With respect to reserve margins, $\left(R M_{w}\right)$ and $\left(R M_{s}\right)$ measure the relationship between water supply and demand, and land supply and demand, respectively. Therefore, Water Project Prioritization $\left(P_{w}\right)$ and Land Projects Prioritization $\left(P_{S}\right)$ are defined as follows in Equations (6) and (7), respectively:

$$
\begin{gathered}
P_{w}=\left\{\begin{array}{c}
R M_{w} * C F_{s}, \quad R M_{w}<0.1 \\
R M_{w} *\left(C F_{s}+C F_{e n}\right), 0.1<R M_{w}<0.6 \\
R M_{w} *\left(C F_{s}+C F_{e n}+C F_{e c}\right), R M_{w}>0.6
\end{array}\right. \\
P_{s}=\left\{\begin{array}{c}
R M_{s} * C F_{s}, \quad R M_{s}<0.1 \\
R M_{s} *\left(C F_{s}+C F_{e n}\right), 0.1<R M_{s}<0.6 \\
R M_{s} *\left(C F_{s}+C F_{e n}+C F_{e c}\right), R M_{s}>0.6
\end{array}\right.
\end{gathered}
$$

The available investment remains to be defined, which corresponds to the relationship between the budget available for investment in projects and incentives for green projects. For the proposed model, the Available Investment Variable (I) will have an initial value of fifty million pesos, and will be varied in order to obtain different analysis scenarios. On the other hand, the incentives for green projects $I_{p}$ are defined as the stimuli for the initiatives in sustainable development and, in this case, correspond to the average between the decision to invest in water and the decision to invest in land 
$\left(D_{\text {water }} D_{\text {soil }}\right)$, multiplied by investment $I$. Investment decisions are step functions that depend on their respective reserve margins, and they are shown in Equations (8) and (9):

$$
\begin{gathered}
D_{\text {water }}=\left\{\begin{array}{c}
1, R M_{w}<0.1 \\
0.6,0.1<R M_{w}<0.6 \\
0.1, R M_{w}>0.6
\end{array}\right. \\
D_{\text {water }}=\left\{\begin{array}{c}
1, R M_{s}<0.1 \\
0.6,0.1<R M_{s}<0.6 \\
0.1, R M_{s}>0.6
\end{array}\right.
\end{gathered}
$$

Table 3, shown below, presents the parameters used during the simulations, their description, the units of measurement of each for them, and the source from which they were obtained. It is important to note that the budget available for investment may change, but—for this research—an average value of 50 million Colombian pesos was assumed. This amount is adjustable according to the financial circumstances established by each municipality.

\begin{tabular}{|c|c|c|c|c|}
\hline Parameter & Description & Value & Units & Source \\
\hline Water Input Rate & $\begin{array}{l}\text { Amount of water provided by the different } \\
\text { tributaries in the area per year }\end{array}$ & 22 & $\%$ & [34] \\
\hline Unused Water Rate & $\begin{array}{l}\text { Amount of water not consumed or used } \\
\text { per year }\end{array}$ & 45 & $\%$ & [32] \\
\hline $\begin{array}{l}\text { Variable Consumption } \\
\text { of Water }\end{array}$ & $\begin{array}{l}\text { Amount of water consumed above the } \\
\text { annual average }\end{array}$ & 60 & Cubic meters & [32] \\
\hline $\begin{array}{l}\text { Fixed consumption } \\
\text { of water }\end{array}$ & Amount of water consumed per year & 130 & Cubic meters & [32] \\
\hline Population & Number of inhabitants & 50 & people & [33] \\
\hline Price of Water & Value paid per $\mathrm{m}^{3}$ of water & 6000 & Pesos & [32] \\
\hline Available budget & Amount of money available for investment & 50 & Million pesos & $\begin{array}{c}\text { Model } \\
\text { Assumption }\end{array}$ \\
\hline Price of Land & Average value paid per hectare of land & 150 & Thousands pesos & [34] \\
\hline Land Use & Amount of land consumed per year & 9000 & hectares & [34] \\
\hline Intended use of land & $\begin{array}{l}\text { Proportion of land (of the total) planned to be } \\
\text { used for the following years }\end{array}$ & 30 & $\%$ & [33] \\
\hline Land Use Rate & Proportion of land (of the total) used each year & 15 & $\%$ & [33] \\
\hline Total Land & Total hectares of land (used and unused) & 515 & $\begin{array}{l}\text { thousands of } \\
\text { hectares }\end{array}$ & [33] \\
\hline
\end{tabular}

Table 3. Parameters used for the model simulation.

\section{Simulations and Analyses}

The following simulations confirm the hypothesis that was raised at the beginning. On the one hand, the balance cycles B1 and B4, shown in Figure 8, indicate the ways in which the change in the levels of supply and demand of water or land, represented in the defined margins, generate key information, by way of alerts, which allow for the proper monitoring of investments.

On the other hand, we observed the ways in which the reinforcement cycle (R3) is influenced by the citizen factors that were established through community participation. According to Figure 9, it is evident that the community of the vereda El Pesebre gives preference to projects related to water, that is, those in which its water sources can be used for an economic purpose by its inhabitants. 


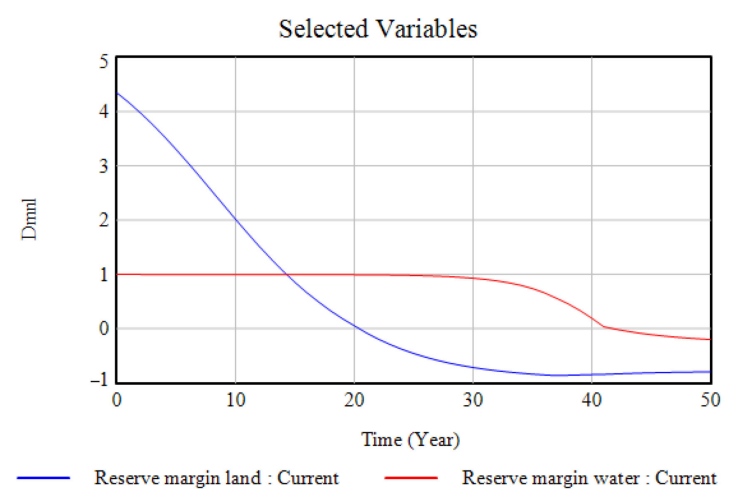

Figure 8. Changes in water and land supply and demand levels.

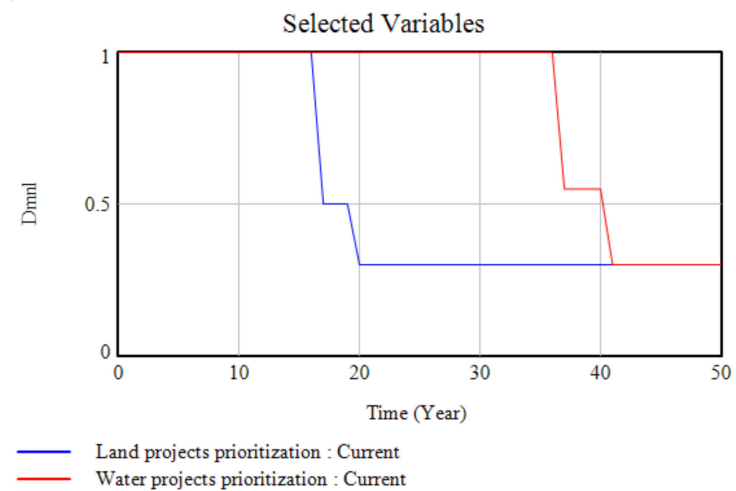

Figure 9. Prioritization of projects according to the citizen factor.

However, despite this strong interest, the current reality shows that the land projects are the privileged ones. This situation is not associated with a factor of reduction or scarcity of water, but is directly related to the financial support for the development of projects related to land use. Thus, the interest that apiculture and livestock projects have received in the community is hardly normal, since large areas of land can be used with minimal investment. In addition, such projects are, in part, sponsored by the local government and some cooperatives in the region.

Figures 10 and 11 show the ways in which investment decisions are, to some extent, influenced by the citizen factors that represent local knowledge in relation to the needs and expectations of the community. This can give clear light to decision-makers, perhaps not to choose the projects that are acceptable to governments or institutions at the financial or political level, but rather the ones that are most suitable for the community. In the case of vereda El Pesebre, the fact that the citizen factors gave priority to water and social projects highlights, in the first place, its lack of sanitary infrastructure, aqueducts and sewerage, drinking water, and solid waste disposal; secondly, it highlights their willingness to undertake economic and environmental projects, such as eco-tourism, in which water sources and the Nevado del Cocuy National Natural Park are the main attractions.

While the reserve margins provide decision-makers with an overview of the projects that can be carried out in the area and, in addition, allow the taking stock of resources in order to avoid shortages, we observed that local knowledge acts in crisis situations. Thus, for example, Figure 12 shows that, in the face of a possible shortage of water, the citizen factors prioritize the initiatives that impact water in order to strengthen those economic activities that require it, thus maintaining the standard of living of the inhabitants. 


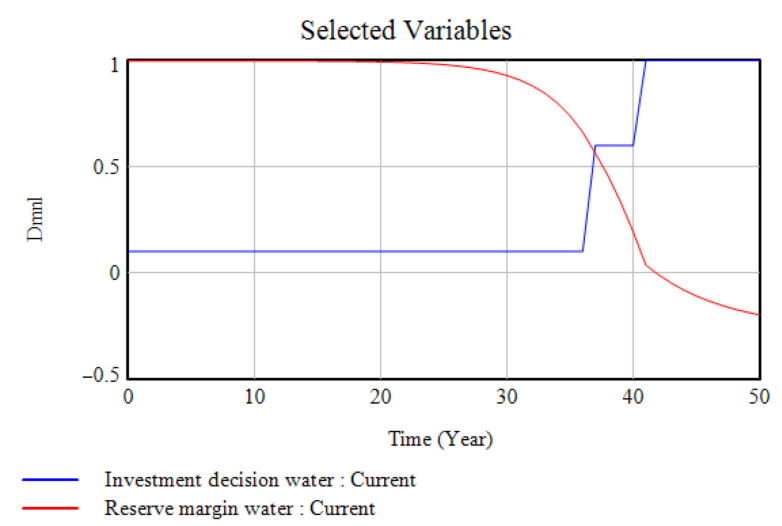

Figure 10. Influence of citizen factors on investment decisions (water).

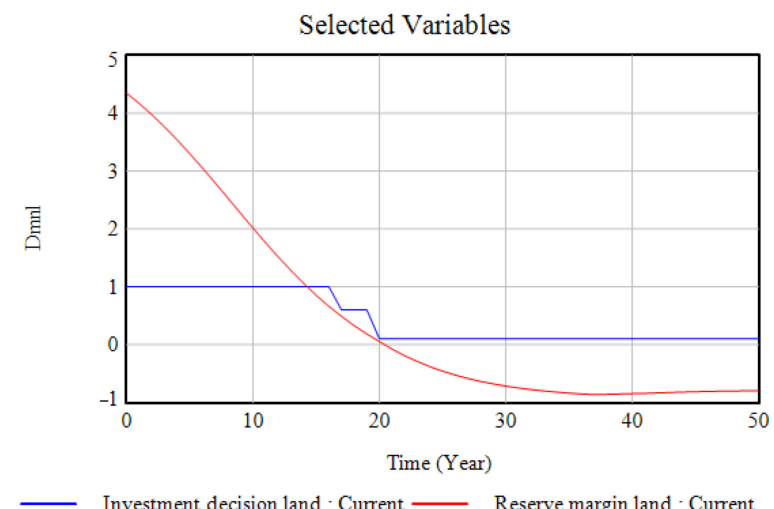

Figure 11. Influence of citizen factors on investment decisions (land).

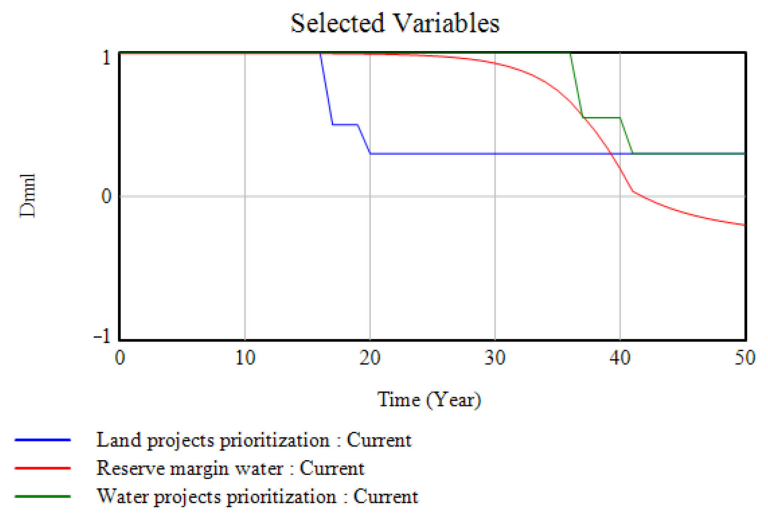

Figure 12. Response of the citizen factors to a possible scarcity of resources.

Moreover, although it can be said that vereda El Pesebre has a notorious abundance of water and land resources, which allows the reserve margins to be positive even during the summer season (information obtained from an activity, called the seasonal calendar, carried out in the participatory workshop), the citizen factors again incline the decision-making, in this case, towards economic projects that influence the improvement of the quality of life of the population, as shown in Figures 13 and 14. At this point, it is the expectations of the population that are expressed in the model. Because, as mentioned above, there is a positive reserve margin for both variables, it is feasible to carry out any project (in water or land) and obtain good results. 


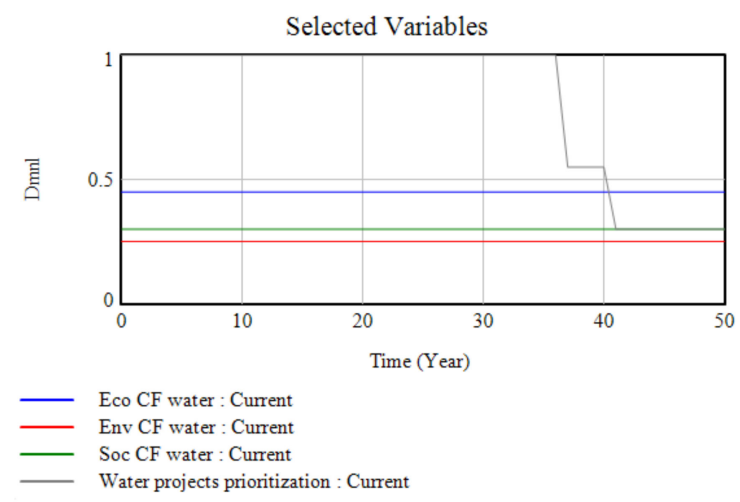

Figure 13. Preference for water-related projects favoring the region's economy.

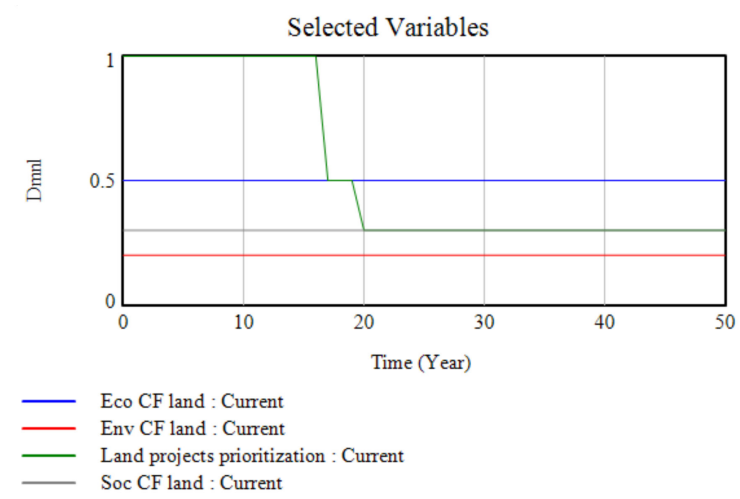

Figure 14. Preference for land-related projects favoring the region's economy.

\section{Preliminary Discussion}

In the evaluation and prioritization of green projects, decision-making rarely focuses on the availability of natural resources and the citizen factors of the place in which the initiatives will be carried out. These are key elements that can help not only in the control and protection of the environment, but also in the management of investments and incentives for the selection of projects to be implemented in an appropriate manner and to be successful in meeting-as expressed by Reed [16] and Stringer et al. [35] — the needs and perhaps even the expectations of a community.

Additionally, because project decisions must be adjusted to the available investment resources, it is necessary to take extra care in their selection. In addition to the assessment of the quality of the proposals or the results obtained in other communities, significant environmental and economic aspects of the locality will also be taken into account, as well as the social conditions that, as mentioned in Johnson et al. [36], can determine the success or failure of a project to some extent [37].

An approximation to the above problem is made in Castrillon-Gomez, Valencia-Calvo, and OlivarTost [27], in which system dynamics is an appropriate tool for achieving the objective of representing part of the social, environmental, and economic dynamics of a community and, at the same time, integrating quantitative variables, such as the investment and reserve margins of natural resources, as well as qualitative variables, such as the needs and expectations of the community, as reflected by the citizen factors.

However, as mentioned in Castrillón-Gomez, Orozco-Orozco, Valencia-Calvo and Olivar-Tost [28], the concept of the qualitative evaluation and prioritization of projects has different connotations when it comes to sustainable development, and in a post-conflict context, such as the one currently characterizing vereda El Pesebre and many other communities in Colombia, it would also be expected to break with the homogenization of initiatives and particular interests in order to achieve a relevant integration between the community, research (academia), and decision-making (project selection). 
Therefore, there is still a need to link various valuation methods in order to achieve a systemic assessment. At this point, the system dynamics through which—as expressed in Forrester [17,31]—it is possible to adequately represent a part of reality is presented, in the first place, as an alternative for the answering of the problem under investigation. Studies-such as those presented in Davies and Simonovic [24], Ahmad and Simonovic [38,39], Azmi and Sarmadi [40], and Azmi and Heidarzadeh [41]—succeed in modeling sustainable development systems by exploring some main axes, such as production, population, water and land use, climate, and ecological footprint, etc., using methodologies like system dynamics and participatory modeling.

Second, the dynamical systems defined in Aracil and Gordillo [42,43] and, subsequently, in Sterman [21] and Vennix [44] as the set of equations through which model behaviors are simulated and analyzed, are increasingly used, and their usefulness is highlighted in decision-making based on constructed analyses and simulations. Some research that shows it has been used, for example, to estimate ecological footprints and water footprints, and also to determine the supply and demand of water and land. In this way, it helps to improve the management of natural resources $[25,45,46]$.

The use of participation and social learning tools presented in the research of authors such as Tàbara and Pahl-Wost [47], Pahl-Wostl [48], and Little, Hester, and Carey [49], among others [26,50-55] allows different types of analyses or diagnoses, which can be experimental, participatory, or statistical, to be carried out. The choice of one of these tools will depend not only on the community, but also on the needs, time, and resources available.

However, the limitations that were presented due to the lack of technical, planning, and project information, specifically related to vereda El Pesebre, led us to use the existing statistical data of the municipality of Tame (some from 2013) in order to complete the calibration of the proposed model. In this sense, two assumptions were made: first, concerning the available budget and incentives for green projects, an amount of 50 million Colombian pesos was estimated per project (approximately 13,000 dollars), after reviewing several of the plans implemented in previous years in the rural areas of the municipality of Tame, to which vereda El Pesebre belongs, and in which the average allocation corresponded to this amount. The second assumption, as was already explained in Section 6, was related to the scarce technical information on the rivers that cross vereda El Pesebre, so the data on the river Tame were assumed, because it has similar characteristics and is close to the town center of vereda El Pesebre. On the other hand, for the simulations that were carried out using the Vensim software, a simulation horizon of 50 years and an integration step of 1 was configured.

With regard to the validation of both the system dynamics model and the dynamic systems model, the expert approach was used, looking essentially for logical consistency between the numerical results and the graphs obtained, in addition to the dimensional consistency in the units and the results obtained in the equations. Finally, appropriate adjustments were made to the parameters by comparing the results with reality.

Consequently, this research made several contributions to the literature. First, the methodological contribution presented through the integration of the PRA and Systems Dynamics consolidates citizen participation as a key factor for decision-making, leading to the selection of successful projects. Second, the case study carried out in the community of El Pesebre contributes to the strengthening of the methodologies used, and demonstrates their applicability and validity for the development of participatory processes, modeling, and decision-making. Likewise, the methodology presented contributes to the evaluation and prioritization of green projects, so that the analysis of proposals is not limited to the completion of bureaucratic procedures, but is rather extended to the consideration of aspects such as the reserve margin of the natural resources, the local knowledge, and the scope of the needs, problems, and even the expectations of the involved community.

\section{Conclusions}

The main objective of this research was to present the integration of participatory modeling with system dynamics as a novel methodology to facilitate decision-making in green projects in post-conflict 
communities in Colombia. The results indicated the different qualities and diverse factors to which the community of vereda El Pesebre is exposed through the development of its different phases (PRA in the first place and dynamic systems in the second place). Likewise, the diagnosis showed not only the problems and needs of the community, but also the way in which they are associated to their geographic location and, consequently, to the availability of the natural resources in the region.

On the other hand, it should be noted that the use of the citizen factors integrated into a 'generalist' model, in which it is possible to adjust certain environmental, social, and economic characteristics of a particular population, can generate relevant information within the same community, which allows for the creation, development, and self-management of projects, as well as the resolution of some local problems, thus building a comprehensive community development that improves the quality of life of its inhabitants.

Likewise, the research demonstrates the ways in which —-through the use of a set of mathematical, qualitative and citizen participation tools-it is possible to model the supply and demand of the natural land and water resources. Based on this, it is possible to support decision-making regarding the evaluation and prioritization of the green projects that are planned to be developed in the short, medium, and long term. In addition, it allows for the generation of public policies for the control of water and land resources, and the solution or mitigation of existing problems.

With respect to social participation, it is possible to show the ways in which the integration of local values and knowledge into the proposed sustainable development model can increase social learning capacities, as well as self-recognition, self-assessment, and the proposal of solutions. In this sense, it can generate benefits and improve the quality of life of the community. The research, moreover, had positive implications within the community. It evidenced environmental awareness and highlighted the existing inequity vis-à-vis other communities that did not suffer from armed conflict and the need to take action in this regard, which will lead to the closing of this gap. On the other hand, it highlighted the interest in the environment and raised concerns about knowing and undertaking tourism-type projects, as well as generating alliances, improving management with the local government, and enhancing its main productive activities. The foregoing supported the unity of the community, its sense of belonging, and its willingness for change.

It is worth highlighting the advantages that are obtained from the use of the proposed methodology, and noting that they would not have been achieved in their entirety without the application of such a methodology. First, the learning, reflection, and social action processes generated in the community were strengthened; second, the environment was recognized, and the scope of local needs was understood, and they were transformed into citizen factors that are rarely used by central government bodies to prioritize green projects.

The future challenges of this methodological proposal will be focused on two main points: first, concerning the use of the methodology as a tool for sustainable development in post-conflict communities in Colombia; second, related to the consolidation of the method as a tool for the planning, evaluation and prioritization of projects for central and local government bodies and other entities involved in the development of the region and the improvement of the quality of life of its inhabitants.

In this way, future research could aim to use the results obtained by applying this methodology as key decision criteria, establishing whether such criteria correspond to a hierarchical order or, on the contrary, if there is evidence of dependency between them, leading to an appropriate selection of one of the existing multi-criteria decision methods. Thus, the decision-making for the evaluation and prioritization of green projects will be conducted in a more accurate way through methods that minimize the possible existing biases and, at the same time, retain the knowledge and priorities identified in participatory processes with the community.

Finally, it should be noted that the introduction of citizen factors into a system dynamics model, and the application of the concepts of supply and demand for natural resources are not common practices when it comes to the evaluation and prioritization of green projects. Hence, their impact can 
be expanded and may be decisive not only in improving investment decisions but also in increasing social learning and community empowerment.

Author Contributions: Conceptualization, J.A.C.-G. and G.O-T.; methodology, J.A.C.-G. and J.V.-C.; software, J.A.C.-G. and J.V.-C.; validation, G.O.-T., J.V.-C.; formal analysis, J.A.C.-G. and J.V.-C.; investigation, J.A.C.-G.; resources, G.O.-T., J.V.-C. and J.A.C.-G.; data curation, J.V.-C.; writing-original draft preparation, J.A.C.-G.; writing-review and editing, J.V.-C. and G.O.-T.; visualization, J.A.C.-G.; supervision, G.O.-T. and J.V.-C.; project administration, J.A.C.-G.; funding acquisition, J.A.C.-G., G.O.-T. and J.V.-C. All authors have read and agreed to the published version of the manuscript.

Funding: This research was funding by the National Doctorate Program (call N 727 of 2015) of Colciencias, which is now the Ministry of Science, Technology, and Innovation of Colombia.

Acknowledgments: The authors especially thank the National Doctorate Program (call N $\mathrm{N}^{\circ} 727$ of 2015) of Colciencias, which is now the Ministry of Science, Technology, and Innovation of Colombia. Furthermore, the authors thank the National University of Colombia, as well as the University of Aysén in Chile, for their support for this type of research. Julián Castrillón-Gómez expresses his thanks to the United Nations Development Programme (UNDP) in the department of Arauca and the entire team of the association Granja Integral Tamarindo (GRANITA) for their support in the realization of the participatory workshops. Likewise, the authors express their gratitude to the whole community of vereda El Pesebre for their determined collaboration and participation during the development of the workshop.

Conflicts of Interest: The authors state that they do not have any conflict of interest.

\section{References}

1. Ananda, J. Implementing Participatory Decision Making in Forest Planning. Environ. Manag. 2007, 39, 534-544. [CrossRef] [PubMed]

2. Hurlbert, M.A.; Gupta, J. The split ladder of participation: A diagnostic, strategic, and evaluation tool to assess when participation is necessary. Environ. Sci. Policy 2015, 50, 100-113. [CrossRef]

3. Arnstein, S.R. Journal of the American Planning Association A Ladder of Citizen Participation. J. Am. Inst. Plan. 1969, 35, 216-224. [CrossRef]

4. Chambers, R. Participatory rural appraisal (PRA): Challenges, potentials and paradigm. World Dev. 1994, 22, 1437-1454. [CrossRef]

5. Chambers, R. Participatory rural appraisal (PRA): Analysis of experience. World Dev. 1994, 22, 1253-1268. [CrossRef]

6. Campbell, J.R. Participatory Rural Appraisal as Qualitative Research From Participatory Claims. Hum. Organ. 2001, 60, 380-389. [CrossRef]

7. Häsler, B.; Msalya, G.; Roesel, K.; Fornace, K.; Eltholth, M.; Sikira, A.; Kurwijila, L.; Rushton, J.; Grace, D. Using participatory rural appraisal to investigate food production, nutrition and safety in the Tanzanian dairy value chain. Glob. Food Secur. 2019, 20, 122-131. [CrossRef]

8. Menconi, M.; Grohmann, D.; Mancinelli, C. European farmers and participatory rural appraisal: A systematic literature review on experiences to optimize rural development. Land Use Policy 2017, 60, 1-11. [CrossRef]

9. Leurs, R. Current challenges facing participatory rural appraisal. Public Adm. Dev. 1996, 16, 57-72. [CrossRef]

10. White, L.; Taket, A. Beyond appraisal: Participatory Appraisal of Needs and the Development of Action (PANDA). Omega 1997, 25, 523-534. [CrossRef]

11. Lara, C.S.; Crispín, A.F.; Téllez, M.C.L. Participatory rural appraisal as an educational tool to empower sustainable community processes. J. Clean. Prod. 2018, 172, 4254-4262. [CrossRef]

12. Pratt, B.; Loizos, P. Choosing Research Methods: Data Collection for Development Workers; Oxfam: Oxford, UK, 1992.

13. Wals, A. Back-alley Sustainability and tl1e Role of Environmental Education. Local Environ. 1996, 1, $299-316$. [CrossRef]

14. Wals, A. Action Research and Community Problem-solving: Environmental education in an inner-city. Educ. Action Res. 1994, 2, 163-182. [CrossRef]

15. Ling, R.S.J. The PRA tools for qualitative rural tourism research. Syst. Eng. Procedia 2011, 1, $392-398$. [CrossRef]

16. Reed, M. Stakeholder participation for environmental management: A literature review. Biol. Conserv. 2008, 141, 2417-2431. [CrossRef] 
17. Forrester, J.W. Industrial Dynamics; The MIT Press: Cambridge, MA, USA, 1961.

18. Bottero, M.; Datola, G.; De Angelis, E. A System Dynamics Model and Analytic Network Process: An Integrated Approach to Investigate Urban Resilience. Land 2020, 9, 242. [CrossRef]

19. Egilmez, G.; Tatari, O. A dynamic modeling approach to highway sustainability: Strategies to reduce overall impact. Transp. Res. Part A Policy Pract. 2012, 46, 1086-1096. [CrossRef]

20. Zhang, X.; Wu, Y.; Shen, L.; Skitmore, M. A prototype system dynamic model for assessing the sustainability of construction projects. Int. J. Proj. Manag. 2014, 32, 66-76. [CrossRef]

21. Swanson, J. Business Dynamics-Systems Thinking and Modeling for a Complex World. J. Oper. Res. Soc. 2002, 53, 472-473. [CrossRef]

22. Valencia-Calvo, J.; Franco, C.J.; Tost, G.O.; Dyner-Rezonzew, I. Enfoque metodológico para el estudio y representación de comportamientos complejos en mercados de electricidad. Ing. Cienc. 2016, 12, 195-220. [CrossRef]

23. Sayyadi, R.; Awasthi, A. An integrated approach based on system dynamics and ANP for evaluating sustainable transportation policies. Int. J. Syst. Sci. Oper. Logist. 2020, 7, 182-191. [CrossRef]

24. Davies, E.G.; Simonovic, S.P. Global water resources modeling with an integrated model of the social-economic-environmental system. Adv. Water Resour. 2011, 34, 684-700. [CrossRef]

25. Cosenz, F.; Noto, G. Applying System Dynamics Modelling to Strategic Management: A Literature Review. Syst. Res. Behav. Sci. 2016, 33, 703-741. [CrossRef]

26. Panebianco, S.; Pahl-Wostl, C. Modelling socio-technical transformations in wastewater treatment-A methodological proposal. Technovation 2006, 26, 1090-1100. [CrossRef]

27. Gómez, J.A.C.; Calvo, J.V.; Olivar-Tost, G. Modelo de evaluación y priorización de proyectos verdes según oferta y demanda de recursos, una integración entre la dinámica de sistemas y el modelado participativo. In Proceedings of the 15th Iberian Conference on Information Systems and Technologies (CISTI 2020), Seville, Spain, 24-27 June 2020; IEEE Computer Society: Washington, DC, USA, 2020.

28. Gómez, J.A.C.; Orozco, N.A.O.; Olivar-Tost, G.; Calvo, J.V. Diagnóstico rural participativo como herrmienta de desarollo en comunidades del postconflicto en Colombia. Unpublished.

29. Redondo-Ortegón, J.M.; Olivar, G.; Ibarra-Vega, D.; Dyner, I. Modeling for the regional integration of electricity markets. Energy Sustain. Dev. 2018, 43, 100-113. [CrossRef]

30. Dyner, I. Energy Modelling Platforms for Policy and Strategy Support. J. Oper. Res. Soc. 2000, 51, 136. [CrossRef]

31. Forrester, J.W. Lessons from system dynamics modeling. Syst. Dyn. Rev. 1987, 3, 136-149. [CrossRef]

32. Caribarare. Indicadores de Control Social de Los Servicios Públicos Domiciliarios de Acueducto, Alcantarillado y Aseo, de la Oficina de Servicios Públicos Domiciliarios del Municipio de Tame, de Acuerdo con el Articulo 1.3.4.6 de la Resolución cra 151 de 2001 año 201. 2019. Available online: https://caribabare.gov.co/esp/wp-content/uploads/2020/04/Indicadores-de-gestión-2019.pdf (accessed on 14 May 2020).

33. Ministerio del Trabajo and PNUD—Programa de Naciones Unidas para el Desarrollo. Perfil Productivo Municipio Tame. Available online: https://issuu.com/pnudcol/docs/perfil_productivo_municipio_tame (accessed on 15 May 2020).

34. Alcaldía de Tame. Plan Basico de Ordenamiento Territorial Tame. Available online: http://tamearauca.gov.co/Transparencia/PBOT/Cap\%C3\%ADtulo\%201\%20Planificaci\%C3\%B3n\%20-\%20Libro\%203\% 20Diagn \%C3\%B3stico\%20-\%20Dimensi\%C3\%B3n\%20F\%C3\%ADsica\%20Bi\%C3\%B3tica.pdf (accessed on 18 May 2020).

35. Stringer, L.C.; Fleskens, L.; Reed, M.; De Vente, J.; Zengin, M. Participatory Evaluation of Monitoring and Modeling of Sustainable Land Management Technologies in Areas Prone to Land Degradation. Environ. Manag. 2013, 54, 1022-1042. [CrossRef]

36. Johnson, K.A.; Dana, G.; Jordan, N.R.; Draeger, K.J.; Kapuscinski, A.R.; Olabisi, L.K.S.; Reich, P.B. Using Participatory Scenarios to Stimulate Social Learning for Collaborative Sustainable Development. Ecol. Soc. 2012, 17. [CrossRef]

37. Größler, A. System dynamics projects that failed to make an impact. Syst. Dyn. Rev. 2007, 23, 437-452. [CrossRef]

38. Roach, J.; Tidwell, V. A Compartmental-Spatial System Dynamics Approach to Ground Water Modeling. Ground Water 2009, 47, 686-698. [CrossRef] [PubMed] 
39. Ahmad, S.; Simonovic, S.P. System Dynamics Modeling of Reservoir Operations for Flood Management. J. Comput. Civ. Eng. 2000, 14, 190-198. [CrossRef]

40. Azmi, M.; Sarmadi, F. Dynamic modelling of water resources sustainable development using a mathematical approach. KSCE J. Civ. Eng. 2015, 19, 1675-1680. [CrossRef]

41. Azmi, M.; Heidarzadeh, N. Dynamic modelling of integrated water resources quality management. Proc. Inst. Civ. Eng.-Water Manag. 2013, 166, 357-366. [CrossRef]

42. Aracil, J. Gordillo, F. Dinámica de Sistemas; Alianza: Madrid, Spain, 1997.

43. Aracil, J. Introducción a la Dinámica de Sistemas; Alianza: Madrid, Spain, 1983.

44. Vennix, J.A.M. Group model-building: Tackling messy problems. Syst. Dyn. Rev. 1999, 15, 379-401. [CrossRef]

45. Newell, B. Simple models, powerful ideas: Towards effective integrative practice. Glob. Environ. Chang. 2012, 22, 776-783. [CrossRef]

46. Newell, B.; Proust, K. I See How You Think: Using Influence Diagrams to Support Dialogue; ANU Centre for Dialogue: Canberra, Australia, 2009.

47. Tàbara, J.D.; Pahl-Wostl, C. Sustainability Learning in Natural Resource Use and Management. Ecol. Soc. 2007, 12, 1-15. [CrossRef]

48. Pahl-Wostl, C. The Importance of Social Learning in Restoring the Multifunctionality of Rivers and Floodplains. Ecol. Soc. 2006, 11. [CrossRef]

49. Little, J.C.; Hester, E.T.; Carey, C.C. Assessing and Enhancing Environmental Sustainability: A Conceptual Review. Environ. Sci. Technol. 2016, 50, 6830-6845. [CrossRef]

50. Tàbara, J.D.; Elmqvist, B.; Ilhan, A.; Madrid, C.; Olson, L.; Schilperoord, M.; Valkering, P.; Wallman, P.; Weaver, P. Modelización participativa para la evaluación integrada de la sostenibilidad de los recursos hídricos: El Modelo del Mundo Celular y el Proyecto Matisse. Rev. Int. Sosten. Tecnol. Humanismo 2006, 1, 185-210.

51. Tabara, J.D.; Roca, E.; Madrid, C.; Valkering, P.; Wallman, P.; Weaver, P. Integrated sustainability assessment of water Systems: Lessons from the Ebro River Basin. Int. J. Innovat. Sustain. Dev. 2008, 3, 48-69. [CrossRef]

52. Pahl-Wostl, C.; Hare, M. Processes of social learning in integrated resources management. J. Community Appl. Soc. Psychol. 2004, 14, 193-206. [CrossRef]

53. Cerdeira, J.O.; Santos, R.; Videira, N. Participatory decision making for sustainable development-The use of mediated modelling techniques. Land Use Policy 2006, 23, 44-52. [CrossRef]

54. Ducrot, R.; Van Paassen, A.; Barban, V.; Daré, W.; Gramaglia, C. Learning integrative negotiation to manage complex environmental issues: Example of a gaming approach in the peri-urban catchment of São Paulo, Brazil. Reg. Environ. Chang. 2014, 15, 67-78. [CrossRef]

55. Davies, K.; Fisher, K.; Dickson, M.E.; Thrush, S.F.; Le Heron, R. Improving ecosystem service frameworks to address wicked problems. Ecol. Soc. 2015, 20. [CrossRef]

Publisher's Note: MDPI stays neutral with regard to jurisdictional claims in published maps and institutional affiliations.

(C) 2020 by the authors. Licensee MDPI, Basel, Switzerland. This article is an open access article distributed under the terms and conditions of the Creative Commons Attribution (CC BY) license (http://creativecommons.org/licenses/by/4.0/). 